\title{
Nutritional value of silk flower hay for lambs ${ }^{1}$
}

\section{Aderbal Marcos de Azevêdo Silva ${ }^{3}$, Roberto Germano da Costa ${ }^{4}$, José Morais Pereira Filho ${ }^{3}$, Ivonete Alves Bakke ${ }^{3}$, Katiuscia Menezes da Silva Lôbo ${ }^{3}$, Gerson Edmo Lira Filho², Giovanna Henriques da Nóbrega ${ }^{2}$}

\footnotetext{
${ }^{1}$ Pesquisa financiada pelo CNPq.

2 Universidade Federal da Paraíba/Centro de Ciências Agrárias, Campus Universitário, 58397-000, Areia, PB, Brasil.

3 Universidade Federal de Campina Grande/Centro de Saúde e Tecnologia Rural. Caixa Postal 64, 58700-970, Patos, PB, Brasil.

4 Universidade Federal da Paraíba/Centro de Formação de Tecnólogo, Campus Universitário, 58220-000, Bananeiras, PB, Brasil.
}

ABSTRACT - It was evaluated four levels of silk flower (Calotropis procera S.W.) hay (SFH) as a substitute of sorghum (Sorghum bicolor) hay (SBH) in diet for lambs. Nutritional value of silk-flower hay was determined based on aparent digestibility and on metabolic, productive and economical performance of Santa Inês lambs. It was used twenty-four castrated males at $15.72 \pm 1.92 \mathrm{~kg}$ body weight randomly distributed in four diets with silk-fklower and sorghum hay ratios (100:0, 66:33, 33:66, 0:100), and supplemented with a concentrate mixture based on 50\% roughage:50\% concentrate (weight/weight). Increase in the levels of silk-flower hay in the diet reduced weight gain and nutrient intake and it increased feed conversion and digestibility coeficients of all the nutrients. Nitrogen balance was similar in all levels of silk-flower hay, although there was a tendency of reduction in nitrogen retention at levels $66 \%$ and $100 \%$ of silk-flower hay. At the levels 0 and $33 \%$ of silkflower hay in the diet, dry matter ingestion (170 and $180 \mathrm{~g} /$ day), daily average weight gain (84 and $89 \mathrm{~g} / \mathrm{kg}^{0.75}$ ) and feed conversion (4.99 and 5.02) were satisfactory. Silk-flower hay can represent up to $16.5 \%$ of the total food ingestion or $33 \%$ of the roughage in diet for lambs.

Key Words: Calotropis procera (S.W.), chemical composition, roughage food, semi-arid, sheep, weight gain

\section{Valor nutritional do feno de flor-de-seda para cordeiros}

RESUMO - Avaliaram-se quatro níveis de feno de flor-de-seda (Calotropis procera S.W.) em substituição ao feno de sorgo (Sorghum bicolor) na dieta de cordeiros. O valor nutricional do feno de flor-de-seda foi determinado com base na digestibilidade aparente e no desempenho metabólico, produtivo e econômico de cordeiros Santa Inês. Utilizaram-se 24 machos castrados com peso corporal de 15,72 $\mathrm{kg} \pm$ 1,92 kg distribuídos aleatoriamente em quatro dietas com relações entre feno de flor-de-seda e de sorgo $(100: 0,66: 33$, 33:66 e 0:100) e suplementadas com uma mistura concentrada à base de $50 \%$ de volumos e $50 \%$ de concentrado (peso/peso). O aumento nos níveis de feno de flor-de-seda na dieta diminuiu o ganho de peso e a ingestão de nutrientes e aumentou a conversão alimentar e o coeficiente de digestibilidade de todos os nutrientes. O balanço de nitrogênio foi semelhante em todos os níveis de feno de flor-de-seda, embora tenha havido tendência de redução na retenção do nitrogênio nos níveis 66 e 100\% de feno de flor-de-seda. Nos níveis 0 e 33\% de feno de flor-de-seda na dieta, a ingestão de matéria seca (170 e $180 \mathrm{~g} / \mathrm{dia})$, o ganho médio diário de peso $\left(84\right.$ e $\left.89 \mathrm{~g} / \mathrm{kg}^{0,75}\right)$ e a conversão alimentar $(4,99$ e 5,02) foram satisfatórios. O feno de flor-de-seda pode representar até $16,5 \%$ da ingestão total ou $33 \%$ do volumoso da dieta de cordeiros.

Palavras-chave: alimento volumoso, Calotropis procera (S.W.), composição química, ganho de peso, ovinos, semiárido

\section{Introduction}

The social and economical importance of small ruminants has increased, especially in the semi-arid region of northeastern Brazil, where sheep and goat raising is a widespread activity. Although native forage production is abundant and with high quality during the rainy season, forage quantity and quality become limited during June-toDecember dry season, resulting in a poor performance of domestic ruminants and the necessity to supplement them with both concentrate and roughage fodder to fulfil $l$ their energy and protein demands to avoid weight loss. Thus, the use of highly productive plants adapted to the conditions of the region and able to produce nutrient-rich forage is considered to be a key point to the development of the sheep raising activity in northeastern Brazil (Cunha et al., 2000). Silk-flower (Calotropis procera S.W.) is a plant adapted to the semi-arid conditions of northeastern Brazil, 
which keeps its leaves green during the whole year and produces forage with desirable bromatological characteristics. Andrade et al. (2008) found up to 19,44\% of crude protein and considered silk-flower as a protein and energy alternative food source to ruminants in semiarid regions. However, Madruga et al. (2008) reported that the use of silk-flower hay in the diet of Santa Inez lambs affected animal health and meat $\mathrm{pH}$ when it participated with $50 \%$ or more of the diet, although the general meat quality was not affected.

A correct diet formulation to a determined level of animal production is based, among other factors, on the knowledge of the nutrient requirements of the animal and the nutritive values of the consumed food (Silva et al., 2010). Non-conventional and good quality forage, such as silkflower hay, may improve animal performance and economical results of the sheep raising activity, especially in a region where conventional low-cost native forage is notoriously scarce during most of the year.

The objective of this study was to evaluate food intake and digestibility, and body weight gain of lambs fed different levels of silk-flower hay as a substitute of the commonly used Sorghum bicolor hay.

\section{Material and Methods}

This study was carried out in the Sheep Section of the Universidade Federal de Campina Grande, Patos, PB. During the experiment, average air moisture and minimal and maximal temperatures were, respectively, 49\%, $25,5^{\circ} \mathrm{C}$ and $33.5^{\circ} \mathrm{C}$. Twenty-four Santa Inês lambs with initial body weight of $15.7 \pm .9 \mathrm{~kg}$ and average age of 150 days were kept in individual suspended wood pens $\left(0.8-\mathrm{m}^{2}\right)$ with access to feeder and water.

Silk flower plants, naturally growing in an alluvial soil, had their $5 \mathrm{~cm}$-or-less diameter branches pruned and mechanically chopped (1-to-2 cm particle size) together with leaves, flowers and fruits. Cultivated sorghum at 60 days of age, growing in an alluvial soil, were cut $20 \mathrm{~cm}$ above the soil and mechanically chopped into 1 -to-2 cm particles. Fresh chopped materials were sun dried during 3-to-4 days (circa 10\% moisture), triturated again in the same chopping machine, and stored in raffia bags.

Silk flower hay-free diet was adjusted to the AFRC (1995) recommendations of metabolizable protein and energy, and to the ARC (1980) recommendation of mineral requirements to a daily 200 -g body weight gain.

Animals were fed a roughage fodder:concentrate ratio (1:1, w:w in a dry matter basis) ad libitum twice a day. The roughage fodder consisted of $0 ; 16.7 ; 33.3$ or $50.0 \%$ of silk-flowe hay, and 50.0 ; 33.3; 16.7 or $0 \%$ sorghum bycolor hay, respectively (Table 1 ).

After deworming, the lambs experienced a 14-day-pretrial period of adaptation to the pens, and to the feeding and management diets.

Data on daily total dry matter intake were obtained by subtracting the remaining food from the total offered to each lamb. The total food offered in a day to each lamb corresponded to $20 \%$ more of the consumption observed in the previous day. Silk-flower hay and sorghum bicolor hay and concentrate, as well as the remaining food of each lamb, were sampled during the experiment for determination of dry matter (DM), organic matter (OM), crude protein (CP), neutral (NDF) and acid detergent fiber (ADF), gross energy (GE) and ashes content (Silva \& Queiroz, 2002).

Every 14 days, body weight was measured after a 18-hour fasting period. The experiment lasted for 68 days when each animal reached $30 \mathrm{~kg}$ of body weight. Data on daily dry matter, organic matter and crude protein ( $\mathrm{g}$ and g/ $\mathrm{kg}^{0.75}$ ), and metabolizable energy (ME) (Mcal and Mcal/ $\mathrm{kg}^{0.75}$ ) intake, as well as food conversion and body weight gain were collected.

Sixteen lambs from the above mentioned experiment were used in a digestibility assay which was carried out for 19 days (from day 21 to day 40 of the above mentioned experiment). Four lambs from each treatment were randomly chosen and conveniently housed in metabolism cages provided with the appropriate apparatus to total feces and

Table 1 - Percentage and bromatological composition (DM basis) of the diets with four levels of silk flower hay in substitution of sorghum

\begin{tabular}{|c|c|c|c|c|}
\hline & \multicolumn{4}{|c|}{ Level of silk flower hay (\%) } \\
\hline & 0 & 33 & 66 & 100 \\
\hline \multicolumn{5}{|l|}{ Ingredients (\%) } \\
\hline Sorghum hay & 50.0 & 33.3 & 16.7 & - \\
\hline Silk flower hay & - & 16.7 & 33.3 & 50.0 \\
\hline Corn meal & 10.0 & 10.5 & 11.0 & 11.5 \\
\hline Soybean meal & 39.0 & 39.0 & 38.5 & 38.0 \\
\hline Lime & 0.50 & 0.0 & 0.0 & 0.0 \\
\hline Minerals ${ }^{1}$ & 0.50 & 0.50 & 0.50 & 0.50 \\
\hline Total & 100 & 100 & 100 & 100 \\
\hline \multicolumn{5}{|l|}{ Bromatological compostion } \\
\hline Dry matter $(g / k g)$ & 901 & 901 & 901 & 901 \\
\hline Crude protein ${ }^{2}$ (g/kg) & 207 & 216 & 223 & 260 \\
\hline Gross energy (Mcal/kg de MS) & 4.18 & 4.23 & 4.24 & 4.25 \\
\hline Neutral detergent fiber ${ }^{2}$ (g/kg) & 420 & 400 & 383 & 368 \\
\hline Acid detergent fiber $^{2}$ (g/kg) & 276 & 272 & 268 & 263 \\
\hline Minerals $^{2}(\mathrm{~g} / \mathrm{kg})$ & 74.4 & 81.0 & 87.3 & 93.6 \\
\hline Calcium $^{2}$ (g/kg) & 4.2 & 6.1 & 9.9 & 13.4 \\
\hline Phosphorus $^{2}$ (g/kg) & 3.9 & 3.8 & 3.9 & 3.9 \\
\hline
\end{tabular}

R. Bras. Zootec., v.39, n.12, p.2739-2743, 2010 
urine collection. The lambs continued receiving the same C. procera and sorgum plus concentrate diet described for the previous experiment. The first 14-day data collected in the digestibility assay, according to Berchielli et al. (2006), were the coefficients of digestibility of dry matter, organic matter, crude protein, neutral detergent fiber, acid detergent fiber, and gross energy, and metabolizable energy (ME), digestible energy (DE) and nitrogen balance (NB). The first 14 days were considered the adaptation period to metabolism cages, and the following five days were used to total feces and urine collection. During this period, $10 \%$ of the total feces and urine were sampled and kept frozen for ulterior analyses. Urine samples were treated with $\operatorname{HCl}(1: 1, \mathrm{v}: \mathrm{v})$ and stored in amber glass containers.

Metabolism formulas, according to Blaxter et al. (1982), were the following: $(\mathrm{DE}=\mathrm{CEi}-\mathrm{CEf}), \mathrm{ME}=\mathrm{CEi}-(\mathrm{CEf}+\mathrm{CEu}$ $+\mathrm{EGPD}), \mathrm{EGPDE}=\mathrm{GPD} \times \mathrm{CEi} / 100$, and $\mathrm{GPD}=4.28+0.059$ CDCE in which CEi = ingested crude energy, $\mathrm{CEf}=$ fecal crude energy, $\mathrm{CEu}=$ urine crude energy, EGPD = energy from gaseous products of digestion, GPD = gaseous products of digestion, and CECD = coefficient of digestibility of crude energy.

It was used for this experiment a complete randomized design with four treatments and six replicates for performance study and four replicates for digestibility assay. Analyses of variance and regression analysis of the data were performed using the PROC REG sub-routine from SAS (1999).

\section{Results and Discussion}

Silk flower and sorghum hay dry matter contents were 90.78 and $90.76 \%$, respectively. Contents, in a DM basis, were, respectively, 9.40 and $4.16 \%$ for $\mathrm{CP}, 3.90$ and
3.84 Mcal/kg for CE, 56.01 and $68.90 \%$ for NDF, 39.63 and 42.31\% for ADF, 12.55 and $8.73 \%$ for ash, 2.60 and $0.40 \mathrm{~g} / \mathrm{kg}$ for calcium, and 0.22 and $0.22 \mathrm{~g} / \mathrm{kg}$ for phosphorus. These values were considered similar for both hays, except for CP, NDF and calcium, favoring silk flower hay qualitatively. Crude protein content (9.40\%) in silk flower hay (leaf and stem) was lower than the values reported by Valadares Filho et al. (2001) (19.87\%) and by Andrade et al. (2008) (19,4\%) for a stem and leaf at 70 days of age of this species. The calcium contents reported in the literature for $C$. procera leaves are similar to those found in leaf and stem in the present study [e.g.: Touré et al. (1998) observed 2.6 g calcium/kg in silk flower leaves]. Contents of neutral detergent fiber and acid detergent fiber in leaf and stem in the present study (56.01\% NDF and 39.63\% ADF) were similar to those reported by Lima (2003) and higher than the values found by Valadares Filho et al. (2001) (28.95\% NDF and 20.32\% ADF) (31.10\% NDF and 18.24\% FDA), but acceptable to a roughage fodder component of a diet for ruminants.

Regression analysis detected a significant $(\mathrm{P}<0.05)$ linear effect in the levels of silk flower hay in the diet on DM, OM, CP, GE and NDF coefficients of digestibility and DE and ME contents in the diet, and a linear effect on ADF coefficient of digestiblity (Table 2). The coefficients of digestibility and ME content were higher at $100 \%$ of silk-flower hay in the diet $(\mathrm{P}<0.05)$. The dry matter coefficient of digestibility value (68.74\%) observed for $100 \%$ silk flower hay in the diet (Table 2) was lower than the values reported by Lima (2003) (71.90\%) and Vaz et al. (1998) (73.12\%) in diets with $40 \%$ and $60 \%$ of silk flower hay, respectively, while the neutral detergent fiber coefficient of digestibility (73.83\%) was higher than the one reported by Lima (2003) (66.63\%), certainly due to higher fiber content present in the $100 \%$ SFH diets. The

Table 2 - Means, regression equations, $\mathrm{r}^{2}$ and coefficient of variation (CV) for apparent digestibility, digestible and metabolizable energy according to SFH levels in diet

\begin{tabular}{|c|c|c|c|c|c|c|c|}
\hline & \multicolumn{4}{|c|}{ Silk flower hay level (\%) } & \multirow[t]{2}{*}{ Regression equation } & \multirow[t]{2}{*}{$r^{2}$} & \multirow[t]{2}{*}{ CV (\%) } \\
\hline & 0 & 33 & 66 & 100 & & & \\
\hline \multicolumn{8}{|l|}{ Digestibility } \\
\hline Dry matter & 58.74 & 59.83 & 63.09 & 68.74 & $\hat{Y}=58.74+0.001 x$ & 0.56 & 8.13 \\
\hline Organic matter & 63.00 & 64.09 & 67.41 & 73.00 & $\hat{Y}=63.00+0.001 x$ & 0.52 & 7.24 \\
\hline Neutral detergent fiber & 53.83 & 56.00 & 62.54 & 73.83 & $\hat{Y}=53.83+0.002 x$ & 0.61 & 9.58 \\
\hline Acid detergent fiber & 20.69 & 26.46 & 32.24 & 38.19 & $\hat{Y}=20.69+0.175 x$ & 0.26 & 37.77 \\
\hline Crude protein & 77.58 & 78.23 & 80.19 & 83.58 & $\hat{Y}=77.58+0.0006 x$ & 0.37 & 4.33 \\
\hline Gross energy & 56.10 & 57.62 & 62.19 & 70.10 & $\hat{Y}=56.10+0.0014 x$ & 0.49 & 9.62 \\
\hline Digestible energy (Mcal/kg) & 2.364 & 2.430 & 2.629 & 2.974 & $\hat{Y}=2.364+0.061 x$ & 0.51 & 9.57 \\
\hline Metabolizable energy (Mcal/kg) & 1.932 & 1.990 & 2.162 & 2.462 & $\hat{Y}=1.932+0.053 x$ & 0.42 & 12.18 \\
\hline Final weight $(\mathrm{kg})$ & 27.70 & 27.98 & 21.44 & 17.80 & $\hat{Y}=29.083-0.105 x$ & 0.56 & 12.79 \\
\hline Mean daily weight gain (g/day) & 170.03 & 180.53 & 96.78 & 22.90 & $Y=0.1773+4 * 10^{-4} x-9 * 10^{-6} x^{2}$ & 0.53 & 29.76 \\
\hline Food conversion & 4.99 & 5.02 & 9.17 & 20.93 & $\hat{Y}=5.122-0.098 x+0.002 x^{2}$ & 0.83 & 31.02 \\
\hline
\end{tabular}

$\hat{\mathrm{Y}}=$ dependent variables; and $\mathrm{x}=\%$ of silk flower hay in diet. 
diets with lower NDF levels (Table 1) resulted in higher levels of digestibility (Table 2). This was also observed by Silva et al. (2004) in a study in which NDF ranged from 38 to $66 \%$ and decreased the percentage of digestible DM, OM and ME.

The highest acid detergent fiber coefficient of digestibility (38.19\%) observed for $100 \%$ of SFH in the diet was lower than the value reported by Vaz et al. (1998) (66.45\%) in a diet composed of $60 \%$ of silk flower hay. The highest gross energy coefficient of digestibility (70.10\%) and DE (2974 kcal/kg) were observed for $100 \%$ of silk flower hay in the diet. This value is higher than the one (2900 kcal/kg) reported by Lima (2003). In general, nutrient digestibility was positively affected by increasing levels of silk flower hay in the diet, suggesting that it is more digestible than sorghum hay.

Metabolizable energy tended $(\mathrm{P}<0.09)$ to increase as silk flower hay increased in the diet, with a maximum of $2,462 \mathrm{kcal} / \mathrm{kg}$ at the $100 \%$ level (Table 2). This trend $(\mathrm{P}<0.09)$ was also observed for nutrient digestibility. However, it was not enough to increase the average daily nutrient intake. Body weight gain was reduced after day 40 at levels 66 and $100 \%$ of silk flower hay in the diet, suggesting a residual deleterious effect of this roughage fodder at higher levels of utilization (Figure 1).

Nitrogen retention was $13.29,12.62,5.87$ and $7.73 \%$ for, respectively, 0, 33, 66 and 100\% silk flower hay in the diet. However, the large data dispersion ( $\mathrm{CV}=61 \%)$ precluded detection of significant effect. The highest crude protein coefficient of digestibility combined with the low level of nitrogen retention observed at $100 \%$ silk flower level in the diet implies in a 50\% efficiency (Ef = nitrogen balance/CPCD) reduction in the utilization of digestible protein compared to the optimal efficiency observed at 33\% of silk flower hay in diet.

Average daily intake of DM, OM, CP and ME (g/kg.75) was not significantly affected $(\mathrm{P}>0.05)$ from level 0 to level
$100 \%$ of silk flower hay in the diet, although a trend $(\mathrm{P}<0.08)$ of decrease was observed for all these variables.

The inclusion of silk flower hay in the diet showed a quadratic $(\mathrm{P}<0.05)$ effect on average daily weight gain (ADWG) and food conversion (Table 2). The regression equation for ADWG (in $\mathrm{kg}$ ) was estimated by $\hat{\mathrm{Y}}=$ $0.1773+0.0004 * \mathrm{X}-0.000009 * \mathrm{X}^{2}\left(\mathrm{R}^{2}=0.53\right)$, while food conversion was estimated by $\hat{\mathrm{Y}}=5.122-0.098+0.002 \mathrm{x}^{2}$ $\left(\mathrm{R}^{2}=0.83\right.$ ), and $\mathrm{X}$ represents the level (from 0 to $100 \%$ ) of silk flower hay in the diet in both equations. Estimated ADWG was the highest at 22.22\% silk flower hay in the diet, which resulted in $186.18 \mathrm{~g}$ of ADWG, close to the expected $200 \mathrm{~g}$ of daily body weight gain. This was correlated with the positive effect of silk flower hay on food conversion $(\mathrm{P}<0.01)$. However, daily OM, CP and ME intake was not affected by silk flower hay $(\mathrm{P}>0.05)$.

Silva et al. (2003) reported a daily ME requirement for maintenance of Santa Inês lambs equal to $74.3 \mathrm{kcal} / \mathrm{kg}^{0.75}$. In the present study, ME intake was greater than the double of that value for any level of silk flower hay in the diet, suggesting that ME intake was not a limiting factor for weight gain.

Mean weight gain linearly increased over time at levels 0 and $33 \%$ of silk flower hay in the diet, while at 66 and $100 \%$ levels the effect was quadratic (Figure 1). The highest estimated value for ADWG was the highest on day 50 for level 33\% of silk flower hay (248 g/day), and on day 40 for levels 66 (160 g/day) and 100\% (107g/day) (Figure 2). Similar results are reported by Melo et al. (2001), when neither clinical nor serum enzymatic alterations were detected in animals submitted to a $60 \%$ diet of chopped and dried C. procera leaves during 40 days, and by Vaz et al. (1998), who reported an increase in food intake during a 42-day period in which up to $60 \%$ of silk flower hay was included in the diet. The reduction in weight gain observed in the present study may be due to anti-nutritional factors (cardiotonic glycosides) present in C. procera that, although at a lower

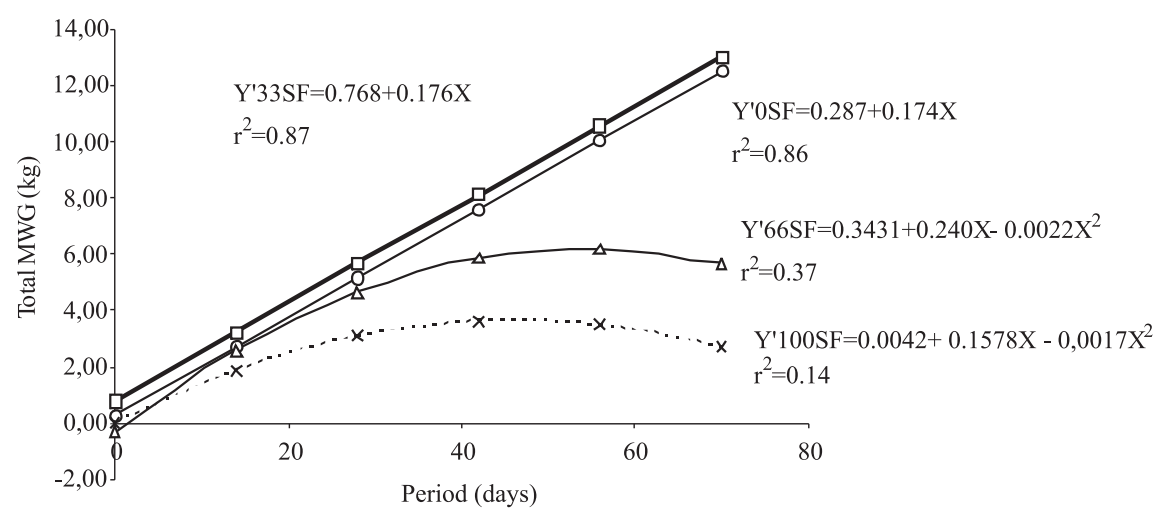

Figure 1 - Average weight gain according to the number of days with silk flower hay in the diet. 


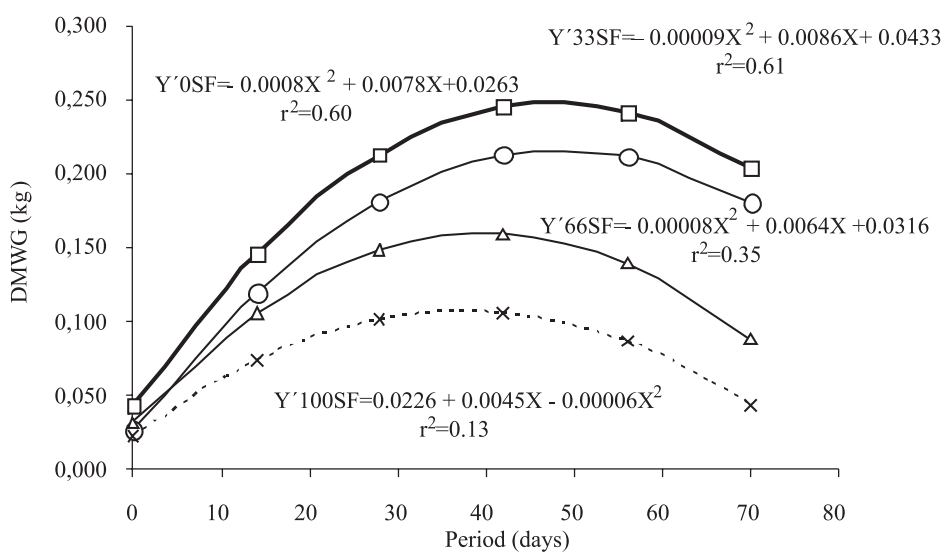

Figure 2 - Average daily weigh gain according to the number of days with silk flower hay in the diet.

level in dried forage, may still show a cumulative deleterious effect (Melo et al., 2001). Ingestion of cardiotonic glycosides results in anorexia and diarrhea, and both symptoms were shown by the experimental animals, which received the two highest levels of silk flower hay. Also, it is reasonable to suppose that the animals diverted energy to physiological processes of detoxification, especially under the $100 \%$ silk flower hay level (i.e.: C procera hay was the exclusive roughage fodder component of the diet).

\section{Conclusions}

The inclusion of silk flower hay in the diet as a substitute of sorghum hay increases nutrient and energy digestibility. It is recommended that silk flower hay participates with $16.5 \%$ of the diet of lambs under a $1: 1$ (w:w) roughage fodder:concentrate ratio.

\section{References}

ANDRADE, M.V.M.; SILVA, D.S.; ANDRADE, A.P. et al. A.Produtividade e qualidade da flor-de-seda em diferentes densidades e sistemas de plantio. Revista Brasileira de Zootecnia, v.37, n.1, p.1-8, 2008.

AGRICULTURAL AND FOOD RESEARCH COUNCIL - AFRC. Technical committee on responses to nutrients: energy and protein requirement of ruminants. Wallingford: Commonwealth Agricultural Bureaux International, 1995. 159p.

AGRICULTURAL RESEARCH COUNCIL - ARC. The nutrient requirement of ruminal livestock. Farnham Royal: Commonwealth Agricultural Bureaux, 1980. 351p.

BLAXTER, K.L.; FOWLER, U.R.; GILL, J.E. A study of the growth of sheep to maturity. Journal of Agricultural Science, v.98, n.2, p.405-420, 1982.

BERCHIELLI, T.T.; GARCIA, A.V.; OLIVEIRA, S.G. Principais técnicas de avaliação aplicadas em estudo de nutrição. In: BERCHIELLI, T.T.; PIRES, A.V.; OLIVEIRA, S.G. (Eds.) Nutrição de ruminantes. São Paulo: FAPESP/FUNEP, 2006. p.397-421.

CUNHA, E.A.; BERCHIELLI, T.T.; PIREZ, A.V. et al. Nutrição de ruminantes. Produção ovina em pastagens. In: CONGRESSO
NORDESTINO DE PRODUÇÃO ANIMAL, 2., 2000, Teresina. Anais... Teresina: Sociedade Nordestina de Produção Animal, 2000. v.1. p.181-190.

LIMA, A.B. Avaliação nutritiva da silagem de Calotropis procera S.W. em combinação com capim-andrequicé (Leersia hexandra) na dieta de ovinos Santa Inês. 2003. $87 \mathrm{f}$. Dissertação (Mestrado em Zootecnia) - Centro de Ciências Agrárias/Universidade Federal da Paraíba, Areia.

MADRUGA, M.S.; COSTA, R.G.; SILVA, A.M.A. et al. Effect of silk flower hay (Calotropis procera $\mathrm{Sw}$ ) feeding on the physical and chemical quality of Longissimus dorsi muscle of Santa Inez lambs. Meat Science, v.78, p.469-474, 2008.

MELO, M.M.; VAZ, F.A.; GONÇALVES, L.C. et al. Estudo fitoquímico da Calotropis procera (ait) R.Br. e sua utilização na alimentação de caprinos: efeitos clínicos e bioquímicos séricos. Revista Brasileira de Saúde e Produção Animal, v.2, n.1, p.15-20, 2001.

SILVA, A.M.A.; SILVA SOBRINHO, A.G.; TRINDADE, I.A.C.M. et al. Net requeriments of protein and energy for maintenance of wool and hair lambs in a tropical region. Small Ruminant Research, v.49, p.165-171, 2003.

SILVA, A.M.A.; SILVA SOBRINHO, A.G.; TRINDADE, I.A.C.M. et al. Food intake and digestive efficiency in temperate wool and tropic semi-arid hair lambs fed different concentrate:forage ratio diets. Small Ruminant Research, v.55, p.107-115, 2004.

SILVA, A.M.A.; SANTOS, E.M.; PEREIRA FILHO, J.M. et al. Body composition and nutritional requirements of protein and energy for body weight gain of lambs browsing in a tropical semiarid region. Revista Brasileira de Zootecnia, v.39, n.1, p.210-216, 2010.

SILVA, D.J.; QUEIROZ, A.C. Análise de alimentos (métodos químicos e biológicos) 2.ed. Viçosa, MG: Universidade Federal de Viçosa, 2002. 135p.

STATYSTICAL ANALYSIS SYSTEMS - SAS. User's guide: Cary, 1999. 846p.

TOURÉ, S.F.; MICHALET-DOREAU, B.; TRAORE, E. et al. Occurrence of digestive interactions in tree forage based diets for sheep. Animal Feed Science and Technology, v.74, n.1, p.63-78, 1998.

VALADARES FILHO, S.C.; ROCHA JR., V.R.; CAPPELLE, E. R. Tabelas brasileiras de composição de alimentos para bovinos. Viçosa, MG: UFV: DZO; DPI, 2001. 297p.

VAZ, F.A.; GONÇALVES, L.C.; SATURNINO, H.M. et al. Avaliação do potencial forrageiro do algodão de seda (Calotropis procera) I - Consumo voluntário e digestibilidade da MS. In: REUNIÃO ANUAL DA SOCIEDADE BRASILEIRA DE ZOOTECNIA, 35., 1998, Botucatu. Anais... Botucatu: Sociedade Brasileira de Zootecnia, 1998. v.1. p.461-463. 